\title{
Effect of Ethanolic Extract of Different Parts of Plant (Annona Squamosa) on the Fertility of Male Rats
}

\author{
Veena B Kushwaha* and Preeti Singh \\ Department of Zoology, D.D.U Gorakhpur University, India
}

Received: September 27, 2017; Published: October 11, 2017

*Corresponding author : Veena B Kushwaha, Department of Zoology, DDU Gorakhpur University, Gorakhpur-273001, Uttar Pradesh, India, Email: vbkddugkp@gmail.com

\begin{abstract}
Plants, since ancient times, have been used globally across the civilizations as valuable, safe and natural agents of therapeutic, industrial and environmental utilities. From the inception of civilization, humans have relied on plants for their basic necessities like food, shelter, clothing, fuel and health. Of all the uses ascribed to the plants, the curative abilities of plants play an inevitable part as plants sometimes comprise sole source for healing ailments for some civilizations. Plants have also been explored for population control (Annona squamosa) is reported to posses various medicinal effects like insecticidal, antiovulatory and abortifacient. The present study therefore reports the effect of ethanolic effect of leaves, bark and seeds on the fructose level in testis, vas deferens and seminal vesicles, sperm count and sperm motility in rats. A significant decrease $(\mathrm{p}<0.05)$ was observed in the level of fructose in testis, vas deferens and seminal vesicle on exposure to the ethanolic extract of leaves, bark and seeds of plant (Annona squamosa) and a significant $(\mathrm{p}<0.05)$ decrease in sperm count and motility was also observed in the rats exposed to the extracts of plant in comparison to control rats. The decrease in fructose level, sperm count and motility was found to be time and dose dependent. Among the different parts of the plant, leaves, bark and seeds the effects were in the order leaf $<$ bark $<$ seed. The study clearly indicates plant extracts have potential to inhibit male fertility.
\end{abstract}

Abbreviations : (Annona squamosa): Sperm Count; Sperm motility; Fructose level; Testis; Vas deferens; Seminal vesicles

\section{Introduction}

For centuries, since the arousal of civilization medicinal plants have been used as valuable medicines to cure various ailments of both human and animals. Our ancient literature of Ayurvedic, Siddha, Unani and Chinese medicine provides us a lot of information about the usage of plants to fight diseases. Eighty percent population in the developing countries relies on traditional medicines that use plants for their primary health care. De Lazlo and Hanshaw initiated the interest of the use of plants to induce infertility by describing plant material used by primitive people to affect fertility [1]. Kirtikar and Basu in 1918 and in 1933 compiled the work done on the Indian medicinal plants. Indian Council of Medical Research, New Delhi in the year 1976 and 1987 published two volumes on medicinal plants [2-4].

The most important concern in India is over population that needs to be addressed and tackled. The solution to this problem is population control. Various methods are being used to control the increase in population. There are a number of methods available that are in use for female contraception while for male contraception only the barrier method and vasectomy are available. Thus, there is a need to develop multiple male contraceptive methods. The risk in the usage of the drugs has triggered the need to develop newer products from medicinal plants. The World Health
Organization has set up a task force on plant research for fertility regulation with an objective to find new orally active non steroidal contraceptive. Since, then several commonly used plants have been reported to adversely affect male reproductive functions in wildlife and humans. Local surveys of medicinal plants in our region lead us to exploration of pharmacological properties of plant (Annona squamosa).

(Annona squamosa) L. Annonaceae also known as custard apple, is a new world fruit tree that has been naturalized throughout the tropics [5]. It is native of tropical America and West Indies, growing up to 3 to 8 meters tall. The leaves are thin, oblong while the flowers are greenish yellow. The ovoid or conical fruit with a purple knobby skin is very sweet and is eaten fresh or can be used for shakes. The fruit is juicy and creamy white, it may contain up to 40 black seeds. It comprises about 120 genera and more than 2000 species [6]. The phyto-chemistry of the Annonaceae has been reviewed by Leboeuf et al. [7]. The moisture content of A. squamosa fruit was reported more than $70 \%$. The approximate nutritional composition of (A. squamosa) reported was: total carbohydrate $86.5 \%$, protein $7.05 \%$, lipid $0.99 \%$, ash $2.28 \%$, and fiber $10.81 \%$ respectively. The carbohydrates $10.56 \mathrm{gl}^{-1}$, glucose $4.32 \mathrm{gl}^{-1}$, protein $0.22 \mathrm{gl}^{-1}$, lipids $1.05 \mathrm{gl}^{-1}$, fiber $0.0 \mathrm{gl}^{-1}$, citrate $3.53 \mathrm{gl}^{-1}$ respectively were reported 
in (A. squamosa) fruit juices. The $\mathrm{pH}$ of the fruit juices was acidic and the epicarp, mesocarp, and juice of fruits contained potassium, sodium, iron, magnesium, calcium, chloride and bicarbonate. Carbonate was only present in the fruit juices. The juices also contained phosphorous, zinc and copper.

This plant has recently come under intense scrutiny as potential source of the potent biologically active annonaceous acetogenins isolated from the seed and the bark [8]. Analysis of (A. squamosa) seed also reveals the presence of alkaloids [9], terpenoids [10] and saponins [11]. The leaf contains volatile oils. This plant is reported to possess a lot of pharmacological and biological activities due to the presence of these bioactive agents. Hence this paper attempts to explore the effect of ethanolic extract of leaves, bark and seeds of this plant on the fertility of male rats.

\section{Material and Methods}

Annona squamosa was collected from the areas around the Department of Zoology, D.D.U. Gorakhpur University Gorakhpur and Uttar Pradesh, India. Seeds of (Annona squamosa) were collected from fruits while bark and leaves were collected from tree and dried under shade, pulverized by a mechanical grinder and passed through a 50 mesh and stored in airtight containers. The powdered seeds bark and leaves $(50 \mathrm{~g})$ were extracted with ethanol for 48 hours. This ethanolic extract was dried at controlled temperature (40-500c) to yield solid powder that was further used for experiments. Healthy colony bred male albino rat weighting 120-150 grams were used for the experiments. The animals were housed in polypropylene cages and these cages were cleaned regularly to avoid rat smell and to maintain standard hygienic conditions $\left(12 \mathrm{~h}\right.$ light $/ 12 \mathrm{~h}$ dark cycles and $25^{\circ} \mathrm{C} \pm 5^{\circ} \mathrm{C}$ at room temperature).

The rats were acclimatized to laboratory conditions for 10 days and fed with standard diet and water was provided ad (libitum). The protocol for these experiments was approved by the Departmental Ethical Committee of D.D.U. Gorakhpur University, Gorakhpur, Uttar Pradesh, India, 273009. The animals were divided into three groups, containing 16 animals in each group. A group of rats was administered $200 \mathrm{mg} / \mathrm{kg}$ body weight / rat/day of the ethanolic extract of seed, bark and leaves of (Annona squamosa) and other group was administered $300 \mathrm{mg} / \mathrm{kg}$ bodyweight/rat/ day every morning for 28 days. The remaining third group was fed with vehicle of similar dilution without test material and kept as control group. After every $7^{\text {th }}, 14^{\text {th }}, 21^{\text {st }}$ and $28^{\text {th }}$ days both control and treated groups four animals from each group were autopsied under light chloroform anesthesia.

\section{Estimation of fructose}

Fructose was determine by colorimetric method using resorcinol [12,13].

\section{Sperm count and sperm motility}

After anaesthetizing the rats, the caudal epididymis was then dissected. An incision (about $1 \mathrm{~mm}$ ) was made in the caudal epididymis and drops of sperm fluid were squeezed onto the microscope slide and 2 drops of normal saline were added to mobilize the sperm cells. Epididymal sperm motility was then assessed by calculating motile spermatozoa per unit area. Morphology (abnormality) was evaluated on sperm from the caudal epididymis. The total morphological abnormalities were observed as described by Linde et al. [14]. The left and the right cauda epididymis were incised and the sperm were allowed to swim for $15 \mathrm{~min}$. Solution of 1: 10 dilution is made by adding $90 \mathrm{ml}$ of water to $10 \mathrm{ml}$ of sperm suspension. Sperm counts were done by using haemocytometer.

\section{Calculations of sperm count and sperm motility}

$$
\begin{aligned}
& \text { Sperm count }=(\text { dilution }) \times(\text { count in } 5 \text { squares }) \times 0.05 \times 10^{6} \\
& \text { Sperm motility }=(\text { Motile sperm }) /(\text { Total sperm }) \times 100 \\
& \text { Total sperm }=\text { Motile sperm }+ \text { Non-motile sperm }
\end{aligned}
$$

\section{Result and Discussion}

A significant decrease $(\mathrm{p}<0.05)$ was observed in the level of fructose in testis (Table 1) vas deferens (Table 2) and seminal vesicle (Table 3 ) on exposure to the ethanolic extract of leaves, bark and seeds of plant (Annona squamosa). Two-way ANOVA test indicates that variation in the strength of dose and exposure time significantly influenced the level of fructose in the organs studied. Among the different parts of the plant, leaves, bark and seeds the effects were in the order leaf $<$ bark $<$ seed. This was probably due to the presence of greater number active compounds responsible for the effects or more concentration of the compounds in seed than in bark or leaf. A significant $(\mathrm{p}<0.05)$ decrease in sperm count and motility (Table 4) was observed in the rats exposed to the extracts of plant in comparison to control rats. Two-way ANOVA test indicates that variation in the strength of dose and exposure time, significantly $(\mathrm{p}<0.01)$ influence the sperm count and motility

\begin{tabular}{|c|c|c|c|c|c|c|c|}
\hline & \multirow{5}{*}{ Parameters } & \multirow{5}{*}{ Days } & \multirow{5}{*}{$\begin{array}{l}\text { Control Rats } \\
\text { Mean } \pm \text { SE }\end{array}$} & \multicolumn{2}{|c|}{ Treated rats } & \multicolumn{2}{|c|}{ Change in \% } \\
\hline & & & & $200 \mathrm{mg} / \mathrm{kg}$ & $300 \mathrm{mg} / \mathrm{kg}$ & $200 \mathrm{mg} / \mathrm{kg}$ & $300 \mathrm{mg} / \mathrm{kg}$ \\
\hline & & & & Body & Body & Body & Body \\
\hline & & & & Weight & Weight & Weight & Weight \\
\hline & & & & Mean \pm SE & Mean \pm SE & Mean \pm SE & Mean \pm SE \\
\hline \multirow{4}{*}{ Leaves } & \multirow{4}{*}{$\begin{array}{c}\text { Fructose }(\mu \mathrm{g} / \mathrm{mg} \\
\text { tissue })\end{array}$} & 7 & $14.57 \pm 0.04$ & $* 11.80 \pm 0.13$ & $* 9.73 \pm 0.24$ & $80.99 \downarrow$ & $66.79 \downarrow$ \\
\hline & & 14 & $17.27 \pm 0.022$ & $* 10.22 \pm 0.09$ & $* 8.95 \pm 0.29$ & $59.18 \downarrow$ & $49.74 \downarrow$ \\
\hline & & 21 & $20.22 \pm 0.04$ & $* 9.12 \pm 0.02$ & $* 5.37 \pm 0.11$ & $45.11 \downarrow$ & $26.56 \downarrow$ \\
\hline & & 28 & $24.29 \pm 0.13$ & $* 7.3 \pm 0.11$ & $3.50 \pm 0.17$ & $30.06 \downarrow$ & $14.41 \downarrow$ \\
\hline
\end{tabular}
of male rats on exposure to the extracts (Table 4).

Table 1 : Effect of ethanolic extract of (Annona squamosa) leaves, bark and seeds on fructose level in the testis of rat. 


\begin{tabular}{|c|c|c|c|c|c|c|c|}
\hline \multirow{4}{*}{ Bark } & \multirow{4}{*}{$\begin{array}{l}\text { Fructose }(\mu \mathrm{g} / \mathrm{mg} \\
\text { tissue) }\end{array}$} & 7 & $15.16 \pm 0.028$ & $14.14 \pm 0.02$ & $11.28 \pm 0.07$ & $93.27 \downarrow$ & $74.40 \downarrow$ \\
\hline & & 14 & $16.43 \pm 0.19$ & $12.18 \pm 0.09$ & $* 9.25 \pm 0.008$ & $74.14 \downarrow$ & $56.30 \downarrow$ \\
\hline & & 21 & $17.88 \pm 0.19$ & $* 10.97 \pm 0.16$ & $7.15 \pm 0.019$ & $61.35 \downarrow$ & $39.98 \downarrow$ \\
\hline & & 28 & $19.30 \pm 0.074$ & $8.8 \pm 0.21$ & $4.16 \pm 0.019$ & $45.59 \downarrow$ & $21.55 \downarrow$ \\
\hline \multirow{4}{*}{ Seeds } & \multirow{4}{*}{$\begin{array}{l}\text { Fructose }(\mu \mathrm{g} / \mathrm{mg} \\
\text { tissue) }\end{array}$} & 7 & $16.07 \pm 0.38$ & $14.09 \pm 0.04$ & $11.66 \pm 0.23$ & $87.68 \downarrow$ & $72.55 \downarrow$ \\
\hline & & 14 & $19.50 \pm 0.14$ & $13.42 \pm 0.18$ & $10.21 \pm 0.18$ & $68.82 \downarrow$ & $52.35 \downarrow$ \\
\hline & & 21 & $22.84 \pm 0.30$ & $12.24 \pm 0.21$ & $8.6 \pm 0.13$ & $53.59 \downarrow$ & $37.65 \downarrow$ \\
\hline & & 28 & $26.24 \pm 0.29$ & $10.72 \pm 0.09$ & $5.7 \pm 0.05$ & $40.85 \downarrow$ & $21.72 \downarrow$ \\
\hline
\end{tabular}

*indicates significant $(\mathrm{p}<0.05)$ difference between control and treated groups when student ${ }^{\prime} \mathrm{t}^{\prime}$ test is applied between treated and control groups.

+indicates significant $(\mathrm{p}<0.05)$ effect of variation in dose and time on treated rats when Two ways ANOVA was applied between control and treated groups.

Table 2: Effect of ethanolic extract of (Annona squamosa) leaves, bark and seeds on fructose level in the Vas deferens of rat.

\begin{tabular}{|c|c|c|c|c|c|c|c|}
\hline & \multirow{6}{*}{ Parameters } & \multirow{6}{*}{ Days } & \multirow{6}{*}{$\begin{array}{c}\text { Control Rats } \\
\text { Mean } \pm \text { SE }\end{array}$} & \multicolumn{2}{|c|}{ Treated rats } & \multicolumn{2}{|c|}{ Change in \% } \\
\hline & & & & $200 \mathrm{mg} / \mathrm{kg}$ & $300 \mathrm{mg} / \mathrm{kg}$ & $200 \mathrm{mg} / \mathrm{kg}$ & $300 \mathrm{mg} / \mathrm{kg}$ \\
\hline & & & & Body & Body & Body & Body \\
\hline & & & & Weight & Weight & Weight & Weight \\
\hline & & & & & Mean \pm SE & Mean \pm SE & Mean \pm SE \\
\hline & & & & Mean \pm SE & & & \\
\hline \multirow{4}{*}{ Leaves } & \multirow{4}{*}{$\begin{array}{c}\text { Fructose }(\mu \mathrm{g} / \mathrm{mg} \\
\text { tissue) }\end{array}$} & 7 & $12.19 \pm 0.026$ & $* 10.50 \pm 0.02$ & $\begin{array}{c}* 8.34 \pm 0.0 \\
9\end{array}$ & $86.13 \downarrow$ & $68.41 \downarrow$ \\
\hline & & 14 & $15.28 \pm 0.07$ & $* 9.4 \pm 0.015$ & $\begin{array}{c}* 6.5 \pm 0.01 \\
2\end{array}$ & $61.51 \downarrow$ & $42.53 \downarrow$ \\
\hline & & 21 & $17.50 \pm 0.12$ & $* 8.19 \pm 0.16$ & $4.7 \pm 0.30$ & $46.80 \downarrow$ & $26.85 \downarrow$ \\
\hline & & 28 & $20.27 \pm 0.07$ & $6.6 \pm 0.12$ & $* 2.4 \pm 0.22$ & $32.56 \downarrow$ & $11.84 \downarrow$ \\
\hline \multirow{4}{*}{ Bark } & \multirow{4}{*}{$\begin{array}{c}\text { Fructose } \\
(\mu \mathrm{g} / \mathrm{mg} \text { tissue })\end{array}$} & 7 & $23.07 \pm 0.03$ & $20.15 \pm 0.02$ & $\begin{array}{c}17.43 \pm 0.1 \\
6\end{array}$ & $87.34 \downarrow$ & $75.56 \downarrow$ \\
\hline & & 14 & $23.9 \pm 0.23$ & $18.18 \pm 0.03$ & $\begin{array}{c}15.30 \pm 0.1 \\
1\end{array}$ & $76.06 \downarrow$ & $64.01 \downarrow$ \\
\hline & & 21 & $26.13 \pm 0.015$ & $15.12 \pm 0.027$ & $\begin{array}{c}13.82 \pm 0.2 \\
6\end{array}$ & $57.86 \downarrow$ & $52.88 \downarrow$ \\
\hline & & 28 & $27.15 \pm 0.03$ & $14.15 \pm 0.01$ & $\begin{array}{c}10.37 \pm 0.2 \\
2\end{array}$ & $52.11 \downarrow$ & $38.19 \downarrow$ \\
\hline \multirow{4}{*}{ Seeds } & \multirow{4}{*}{$\begin{array}{c}\text { Fructose } \\
(\mu \mathrm{g} / \mathrm{mg} \text { tissue })\end{array}$} & 7 & $15.88 \pm 0.21$ & $14.37 \pm 0.08$ & $\begin{array}{c}13.16 \pm 0.3 \\
2\end{array}$ & $90.49 \downarrow$ & $82.87 \downarrow$ \\
\hline & & 14 & $18.08 \pm 0.034$ & $13.04 \pm 0.40$ & $\begin{array}{c}12.80 \pm 0.1 \\
0\end{array}$ & $72.12 \downarrow$ & $70.79 \downarrow$ \\
\hline & & 21 & $22.62 \pm 0.24$ & $12.10 \pm 0.05$ & $\begin{array}{c}11.13 \pm 0.3 \\
2\end{array}$ & $53.49 \downarrow$ & $49.20 \downarrow$ \\
\hline & & 28 & $26.10 \pm 0.33$ & $11.005 \pm 0.38$ & $\begin{array}{c}10.20 \pm 0.2 \\
3\end{array}$ & $42.16 \downarrow$ & $39.08 \downarrow$ \\
\hline
\end{tabular}

*indicates significant $(\mathrm{p}<0.05)$ difference between control and treated groups when student' $\mathrm{t}^{\prime}$ test is applied between treated and control groups.

+indicates significant $(\mathrm{p}<0.05)$ effect of variation in dose and time on treated rats when Two ways ANOVA was applied between control and treated groups. 
Table 3 : Effect of ethanolic extract of (Annona squamosa) leaves, bark and seeds on fructose level in the Seminal vesicles of rat.

\begin{tabular}{|c|c|c|c|c|c|c|c|}
\hline & \multirow{5}{*}{ Parameters } & \multirow{5}{*}{ Days } & \multirow{5}{*}{$\begin{array}{c}\text { Control } \\
\text { Rats } \\
\text { Mean } \pm \text { SE }\end{array}$} & \multicolumn{2}{|c|}{ Treated rats } & \multicolumn{2}{|c|}{ Change in \% } \\
\hline & & & & $200 \mathrm{mg} / \mathrm{kg}$ & $300 \mathrm{mg} / \mathrm{kg}$ & $200 \mathrm{mg} / \mathrm{kg}$ & $300 \mathrm{mg} / \mathrm{kg}$ \\
\hline & & & & Body & Body & Body & Body \\
\hline & & & & Weight & Weight & Weight & Weight \\
\hline & & & & Mean \pm SE & Mean \pm SE & Mean \pm SE & Mean \pm SE \\
\hline \multirow{4}{*}{ Leaves } & \multirow{4}{*}{$\begin{array}{c}\text { Fructose } \\
\text { ( } \mu \mathrm{g} / \mathrm{mg} \text { tissue })\end{array}$} & 7 & $16.47 \pm 0.16$ & $* 13.58 \pm 0.14$ & $* 11.66 \pm 0.26$ & $82.45 \downarrow$ & $70.79 \downarrow$ \\
\hline & & 14 & $17.69 \pm 0.26$ & $* 11.29 \pm 0.044$ & $* 8.51 \pm 0.26$ & $63.82 \downarrow$ & $48.10 \downarrow$ \\
\hline & & 21 & $19.37 \pm 0.06$ & $9.47 \pm 0.23$ & $* 6.7 \pm 0.12$ & $48.89 \downarrow$ & $34.58 \downarrow$ \\
\hline & & 28 & $21.41 \pm 0.17$ & $8.3 \pm 0.24$ & $5.28 \pm 0.08$ & $38.76 \downarrow$ & $24.66 \downarrow$ \\
\hline \multirow{4}{*}{ Bark } & \multirow{4}{*}{$\begin{array}{c}\text { Fructose } \\
(\mu \mathrm{g} / \mathrm{mg} \text { tissue })\end{array}$} & 7 & $15.32 \pm 0.08$ & $12.99 \pm 0.27$ & $10.19 \pm 0.05$ & $84.79 \downarrow$ & $66.51 \downarrow$ \\
\hline & & 14 & $16.58 \pm 0.075$ & $11.38 \pm 0.07$ & $8.26 \pm 0.07$ & $68.63 \downarrow$ & $49.81 \downarrow$ \\
\hline & & 21 & $17.88 \pm 0.23$ & $9.85 \pm 0.22$ & $6.67 \pm 0.23$ & $55.08 \downarrow$ & $37.30 \downarrow$ \\
\hline & & 28 & $19.24 \pm 0.09$ & $7.9 \pm 0.17$ & $4.7 \pm 0.15$ & $48.45 \downarrow$ & $24.42 \downarrow$ \\
\hline \multirow{4}{*}{ Seeds } & \multirow{4}{*}{$\begin{array}{c}\text { Fructose } \\
(\mu \mathrm{g} / \mathrm{mg} \text { tissue })\end{array}$} & 7 & $18.07 \pm 0.038$ & $* 16.13 \pm 0.086$ & $* 14.50 \pm 0.12$ & $89.27 \downarrow$ & $80.24 \downarrow$ \\
\hline & & 14 & $22.02 \pm 0.62$ & $* 15.30 \pm 0.079$ & $* 13.16 \pm 0.08$ & $69.48 \downarrow$ & $59.62 \downarrow$ \\
\hline & & 21 & $26.41 \pm 0.03$ & $* 14.23 \pm 0.26$ & $* 11.23 \pm 0.27$ & $53.88 \downarrow$ & $42.52 \downarrow$ \\
\hline & & 28 & $30.29 \pm 0.08$ & $* 12.90 \pm 0.27$ & $* 8.76 \pm 0.52$ & $42.58 \downarrow$ & $28.92 \downarrow$ \\
\hline
\end{tabular}

*indicates significant $(\mathrm{p}<0.05)$ difference between control and treated groups when student ${ }^{\prime} \mathrm{t}^{\prime}$ test is applied between treated and control groups.

+indicates significant $(\mathrm{p}<0.05)$ effect of variation in dose and time on treated rats when Two ways ANOVA was applied between control and treated groups.

Table 4: Effect of ethnolic extract of (Annona squamosa) leaves, bark and seeds on sperm count and sperm motility of rats.

\begin{tabular}{|c|c|c|c|c|}
\hline & \multirow{2}{*}{$\begin{array}{c}\text { Sperm } \\
\text { parameters }\end{array}$} & \multirow{2}{*}{$\begin{array}{c}\text { Control Rats } \\
\text { Mean } \pm \text { SE }\end{array}$} & \multicolumn{2}{|c|}{ Treated rats } \\
\hline & & & $\begin{array}{c}200 \mathrm{mg} / \mathrm{kg} \text { Body Weight } \\
\text { Mean } \pm \text { SE }\end{array}$ & $\begin{array}{c}300 \mathrm{mg} / \mathrm{kg} \text { Body Weight } \\
\text { Mean } \pm \text { SE }\end{array}$ \\
\hline \multirow[t]{2}{*}{ Leaves } & $\begin{array}{l}\text { Sperm count } \\
\left(\text { million } / \mathrm{mm}^{3} \text { ) }\right.\end{array}$ & $20.16 \pm 0.021$ & $17.42 \pm 0.026$ & $12.19 \pm 0.18$ \\
\hline & Sperm motility (\%) & $81.89 \pm 0.235$ & $73.43 \pm 0.661$ & $62.53 \pm 0.127$ \\
\hline \multirow[t]{2}{*}{ Bark } & $\begin{array}{l}\text { Sperm count } \\
\left(\text { million } / \mathrm{mm}^{3}\right)\end{array}$ & $20.21 \pm 0.029$ & $15.76 \pm 0.016$ & $10.28 \pm 0.46$ \\
\hline & Sperm motility (\%) & $87.48 \pm 0.345$ & $76.23 \pm 0.287$ & $64.39 \pm 0.268$ \\
\hline \multirow[t]{2}{*}{ Seeds } & $\begin{array}{c}\text { Sperm count } \\
\left(\text { million } / \mathrm{mm}^{3}\right)\end{array}$ & $18.36 \pm 0.044$ & $14.32 \pm 0.038$ & $9.56 \pm 0.24$ \\
\hline & Sperm motility (\%) & $84.82 \pm 0.421$ & $70.21 \pm 0.676$ & $56.46 \pm 0.250$ \\
\hline
\end{tabular}

Fructose is formed almost entirely in the seminal vesicles and is the most important energy source for sperm [15]. The determination of fructose concentration of the seminal vesicle provides clues to secretary function of seminal vesicle which are under testosterone control [16]. The seminal fructose has been suggested to arise from glucose via glycogen phosphohexose pathway in the presence of phosphohexoisomerase and alkaline phosphatase. The process of fructose formation in seminal vesicles is initiated and controlled by the testicular androgens $[17,18]$. A decrease in the fructose level on exposure to leaf, bark and seed extract of the plant affects sperm motility and viability since fructose serves as energy source for the sperm. Fructose is androgen dependent and its decrease indicates reduction in the circulating androgens. Absence of fructose is an indication of obstruction either in vas deferens or the epididymis [19-21].

It is reported by Ahmad et al [22] that percentage of abnormal sperms increases with decrease in the fructose level in epididymis, seminal vesicles and vas deferens. This was evident in the present study also. Depletion of sperm count and sperm motility in the extract treated rats suggests alteration in sperm production in the testes and maturation in the epididymis. The reduction in sperm count and motility in cauda epididymis is important with regard to fertilization [23,24]. Decrease in sperm motility is associated with an increase in the percentage of dead and morphologically abnormal spermatozoa. The decrease in the caudal Epididymal sperm counts when compared to control rats indicates that, the 
extracts of leaves, bark and seeds of (Annona squamosa) can affect one or more aspects of spermatogenesis. It affects the hormonal mechanisms concerned with the regulation of spermatogenesis. The decreased sperm motility observed in the study may be an effect of altered function of the accessory organs [25]. Mishra and Singh [26] also reported decreased sperm count in male albino rats after treatment with aqueous leaf extract of (Azadirachta indica). During the present study depletion of sperm count observed in animals after exposure to plant extracts and decreased number of sperms suggests alteration in the sperm production in testes probably due to disturbances in the process of spermatogenesis as observed by various other researchers while working with different plant products. Changes in both sperm count and motility results in partial infertility within twenty eight days. An abnormal sperm function ultimately gives rise to male sterility. Moreover, in our study, a low fructose concentration with different doses of plant extracts could be another cause of reduction in sperm motility since motile sperm consumes fructose after ejaculation [27-29].

Among the plant based contraceptives, inhibition of male fertility after administration of natural substances has been related to decreased spermatozoa density [30]. For male contraception, it is not necessary to stop spermatogenesis, but it is enough to eliminate the fertilizing ability of the spermatozoa by causing changes in the morphology or in the function of sperm [31].

\section{References}

1. De Laszlo H, Henshaw PS (1954) Plant materials used by primitive peoples to affect fertility. Science 119(3097): 626-631.

2. Kirtikar KR, Basu BD (1918) Indian Medicinal plants published by Sudhindra Nath Basu, MB Panini. Bhuwaneswari Asrama, Balodurganj India, p. 72.

3. Kirtikar KR, Basu BD (1935) Indian Medicinal plants periodical Expert Books Agency Delhi, India 4(2): 2423-36.

4. Kritiker KR, Basu BD (1975) In: Indian Medicinal Plants. Singh Bishen, Singh Mahendra Pal New Canaught Place, Dehradun, India, pp. 785-788.

5. Mortan J(1973) Fruits of warm climate: media Miami, Florida, USA, p. 75-80.

6. Heywood VH (1978) Flowering plants of the world University press, Oxford USA.

7. Leboeuf M, Cave A, Bhaumik PK, Mukherjee B, Mukherjee R (1982) The phytochemistry of the Annonacea. Phytochemistry 21(12): 2783- 2813.

8. Rupprecht JK, Hui YH, McLaughlin JL (1990) Annonaceous acetogenins: a review. J Nat Prod 0 53(2): 237-278.

9. Vohorn SB, Kumar I, Naqvi SAH (1975) Plant Med 28: 97-100.

10. Wong KC, Khoo KH (1993) Flavour and Fragrance Journal 8: 5-10.

11. Fang XP, Rieser MJ, Gu ZM, Zhao GX, Mclaughlin JL (1993) Annonaceous acetogenins: An updated review. Phytochemical analysis 4: 27-48.

12. Foreman D, Gaylor L, Evans E, Trella C (1973) A modification of the Roe procedure for determination of fructose in tissues with increased specificity, Analytical Biochemistry 56(2): 584-590.
13. Roe JH (1934) A colorimetric method for the determination of fructose in blood and urine. J Biol Chem 107: 15.

14. Linde RE, Strader LF, Slot VL, Suarez JD (1992) End points of spermatotoxicity in the rat after short duration exposures to fourteen reproductive toxicants. Reproductive Toxicology 6(6): 491-505.

15. Peterson RN, Freund M (1971) Factors affecting fructose utilization and lactic acid formation by human semen: the role of glucose and pyruvic acid, fertility and Sterility 22(10): 639-644.

16. Schill WB (1976) Fruktosebestimmung im Spermaplasma. Med Klin 71: 1031-1041.

17. Mann T (1964) The biochemistry of semen and of male reproductive tract $\left(2^{\text {nd }} e d n\right)$ London, United Kingdom.

18. Mann T (1974) Secretory function of the prostate, seminal vesicle and other male accessory organs of reproduction. Journal of Reproduction and Fertility, Cambridge 37: 179-188.

19.Zhu JL, Basso O, Obel C, Bille C, Olsen J (2006) Infertility, infertility treatment and congenital malfunctions. Danish natural birth count. BMJ 333 (7570): 679.

20. Gonzales GF (2001) Function of seminal vesicles and their role in male fertility. Asian j andrology 3(4): 251-258.

21. Gonzales GF , Villena A (1997) Influence of low correlated seminal fructose level on sperm chromatin stability in semen from men. Fertile Sterile 67: 763-768.

22. Ahmad M, Ahmad RN, Aldakatti RH, Ghosesawar NG (2002) Reversible antifertility effect of benzene extract of ocimum sanctum leaves on sperm parameters and fructose content in rats. J Basic Clin Physiol Pharmacol 13(1): 51-59.

23. Bedford JM (1979) Evolution of the sperm maturation and sperm storage functions of the epididymis. Baltimore: Urban and Schwarzenberg pp. $7-21$.

24. Raji Y, Bolarinwa AF (1997) Antifertility activity of Quassia amara in male rats - in vivo study. Life Sci 61(11): 1067-1074.

25. Hamilton DW (1975) Structure and function of the epithelium lining the ductuli efferentes, ductus epididymis and ductus deferens in the rat. In: Hamilton DW, Green RO editors. Handbook of Physiology, Section 7 V Washington (DC) American Physiological Society, USA, pp. 259-301.

26. Mishra RK, Singh SK (2005) Effect of aqueous leaf extract of (Azadirachta indica) on the reproductive organs in male mice. Indian J Exp Biol 43(11): 1093-1103.

27. SettyBS (1979) Regulation of Epididymal function and sperm maturationendocrine approach to fertility control in male. Endocrinology 74(1): 100-117.

28. Rao MV, Shah, KD (1988) Endocrine approach to male fertility control by steroid hormone combination in rat Rattus Norvegicus. L Indian journal of Expt Biol 36(8): 775-779.

29. Rao MV, Mathur N (1988) Estrogen induced effects on mouse testis and Epididymal spermatozoa. Experimental and clinical Endocrinology 92: 231-234.

30. Watcho P, Kamtechouing P, Sokeng S, Moundipa PF, Tantchu J, et al. (2001) Reversible antispermatogenic and antifertility activity of (Mondia whitei $L$ ) in male albino rats. Phytotherapy Research. 15: 26-9.

31.Joshi MN, Tandon VL, Munjal A (2009) Evaluation of antifertility potential of aqueous extract of (Bougainvillea spectabilis)_leaves in Swiss albino rats. International Journal of Pharmaceutical sciences and Drug Research 1: 19-23. 


\begin{tabular}{ll}
\hline BIOMEDICAL & Assets of Publishing with us \\
RESEARCHES & Global archiving of articles \\
\hline & - Immediate, unrestricted online access \\
\hline
\end{tabular}

